SILVA DMN; OLIVEIRA FL; DALVI LP; PRATISSOLI D; ERLACHER WA; QUARESMA MAL. 2015. Occurrence of insects causing injuries to the yacon crop. Horticultura Brasileira 33: 394-397. DOI - http://dx.doi.org/10.1590/S0102-053620150000300020

\title{
Occurrence of insects causing injuries to the yacon crop
}

\section{Diego MN Silva; Fábio L Oliveira; Leandro P Dalvi; Dirceu Pratissoli; Wellington A Erlacher; Mateus AL Quaresma}

Universidade Federal do Espírito Santo, UFES-CCA, Alegre-ES, Brasil; diegoufvjm@yahoo.com.br; fabio.oliveira@cca.ufes.br; leandro. dalvi@ufes.br; dirceu.pratissoli@gmail.com; mateusveio@hotmail.com

\begin{abstract}
This research aimed to catalog insects that cause injury to the yacon (Smallanthus sonchifolius, família Asteraceae) crop, in order to identify those who may cause damage. The study was carried out in Alegre, Espírito Santo State, Brazil. Cultivation began in May 2013 and the harvest was done 180 days later. Three species from the Coleoptera order: Lagria villosa (Coleoptera: Lagriidae); Cerotoma arcuata and Diabrotica speciosa (Coleoptera: Chrysomelidae) and two species from the Lepidoptera order: Spodoptera eridania (Lepidoptera: Noctuidae) and Chlosyne lacinia saundersii (Lepidoptera: Nymphalidae) were observed causing damage to the yacon crop. The caterpillar C. lacinia saundersii, known as sunflower caterpillar, was the most important species, being observed throughout the yacon cycle.
\end{abstract}

Keywords: Smallanthus sonchifolius, damage, pest management.

\section{RESUMO}

Levantamento de insetos causando injúrias na cultura de yacon

O objetivo deste trabalho foi catalogar insetos que promovam injúrias em cultivos de yacon (Smallanthus sonchifolius, família Asteraceae), visando identificar aqueles que possam ter potencial para causar danos à cultura. $\mathrm{O}$ trabalho foi desenvolvido no município de Alegre-ES. O cultivo teve inicio no mês de maio de 2013 e a colheita foi feita aos 180 dias após plantio. Foram registradas atacando a cultura três espécies da ordem Coleoptera: Lagria villosa (família Lagriidae), Cerotoma arcuata e Diabrotica speciosa (família Chrysomelidae) e duas da ordem Lepidoptera: Spodoptera eridania (família Noctuidae) e Chlosyne lacinia saundersii (família Nymphalidae). Conhecida como lagarta-do-girassol, a lagarta $C$. lacinia saundersii foi o inseto mais frequente, sendo observada durante todo o ciclo de yacon.

Palavras-chave: Smallanthus sonchifolius, danos, manejo fitossanitário.

(Recebido para publicação em 30 de maio de 2014; aceito em 20 de março de 2015) (Received on May 30, 2014; accepted on March 20, 2015)

Y acon or yacon potato (Smallanthus sonchifolius) is a species of Asteraceae family, from the Andes, and found from Colombia and Venezuela to the northwestern Argentina, at altitudes ranging from 2000 to 3400 meters (Hermann \& Freire, 1998). Recently, many researchers have been interested in this plant due to its potential as functional food, mainly for its composition in oligosaccharides of low degree of polymerization, which can reach $67 \%$ of dry matter soon after harvest (Asami et al., 1991).

Leaves, tuberous roots and rhizophores show great quantity of fructooligosaccharides (FOS), which are considered prebiotics, due to its low digestibility by enzymes in the human gastrointestinal tract, selectively stimulating the growth and activity of intestinal bacteria which are beneficial to health (WHO, 2004). Among FOS, yacon presents the inulin type, with degree of polymerization (Gp) $£ 12$, as reserve carbohydrates, presenting potential in food industry for producing dietetic products and anticariogenic (Vilhena et al., 2000; Moscatto et al., 2004; Genta et al., 2010). Due to this fact, studies on the use of yacon have been carried out in order to assist treatment of diabetes mellitus (Aybar et al., 2001; Genta et al., 2010; Albuquerque \& Rolin, 2011).

The plant consumption has significantly started since the mid-2000s and root has become popularly known as yacon potato or diet potato (Santana \& Cardoso, 2008). Recent recognition of the promising effects on health from yacon consumption increased the commercial interest, creating demand on activities involving yacon growing (Manrique \& Párraga, 2005). In the last three decades, yacon cultivation has been extended to countries outside the Andes, like Paraguay, the United States, Slovakia, China, Korea and Taiwan (Lachman et al., 2004). The migration routes followed by plants was fully identified. In the 80 's, yacon left, for the first time, Ecuador and went up to New Zealand, country in which was well adapted and where it is grown in small scale (Manrique et al., 2004). In 1985, the plant was taken from New Zealand to Japan, country where most scientific research studies, related to agronomic management, chemical 
composition, properties on the health and development of processed products, have been done. Japan was the center from where the root spread to other countries such as Korea and Brazil (Seminario et al., 2003).

In Brazil, the species was introduced around 1989's and early 90 in Capão Bonito region (SP) by Japanese immigrants, and recently in mountain areas in the state of Espírito Santo and Rio de Janeiro (Moscatto et al., 2004; Santana \& Cardoso, 2008; Maier, 2012).

Because this is a relatively recent commercial exploitation plant, yacon has no detailed growing system. Regarding to pest attack, for example, very little information can be found. In small yacon-growing areas in Peru, Seminário et al. (2003) observed some insects which feed themselves by eating the aboveground part, including leaves, sprouts and flowers: Liriomyza sp. (Diptera: Agromyzidae); Diabrotica undecimpunctata and D. speciosa (Coleoptera: Chrysomelidae); Agrotis ipsilon and Copitarsia turbata (Lepidoptera: Noctuidae); Schistocerca sp (Orthoptera: Acrididae), and other two insects of Acrididae and Trydactydae families. The authors also observed slug attack (Agriolimax sp.: Limacidae). Attacking the underground parts, Golofa aegeon (Coleoptera: Scarabaeidae) and Passalus sp. (Coleoptera: Passalidae) were observed. The sucking insects like green leafhopper (Empoasca sp.), showed lower occurrence (Hemiptera: Cicadellidae), and aphids, Aphis sp. and Myzus persicae (Hemiptera: Aphididae).
In season 2001-2002, in the region of Cajamarca, in Peru, a type of red mite (Tetranychus sp.) was noticed attacking the leaves (Seminario et al., 2003).

Yacon leaves have two defense systems: the first consists of a large amount of trichomes which prevent the access of insects. The second system is chemical type, formed by the presence of special glands containing some type of toxic substance, to be identified (Seminario et al., 2003). The combination of these defense mechanisms contributes to yacon leaves suffer fewer insect attacks, making less frequent insects occurrence reports. According to Maldonado et al. (2008), in Argentina, only in sporadic cases farmers perform insect control, usually when the crop is close to other crops such as potatoes and corn.

Because that yacon crop has been implemented recently in our country, no literature on occurrence of insect causing injuries in the crop can be found, however with an increase of growing areas, phytosanitary problems tend to intensify. Given the above, this work aimed to catalog insects that promote injuries in yacon crops, in order to identify those which have the potential to cause damage to the crop.

\section{MATERIAL AND METHODS}

The work was carried out in an experimental field of Centro de Ciências Agrárias da Universidade Federal do Espírito Santo, located in Alegre, Brazil.
After soil chemical analysis, the authors concluded that no correction would be needed; however, planting fertilization using cattle manure equivalent to $40 \mathrm{~kg}$ of nitrogen per hectare was performed. The experimental field was composed of 1800 plants spacing of $1.0 \mathrm{~m}$ between lines and $0.5 \mathrm{~m}$ between plants, in an area of $900 \mathrm{~m}^{2}$. Cultivation began in May 2013 and emergence of the shoots was 30 days after planting (DAP) of the rhizophores. Plants reached the maximum height of $1.53 \mathrm{~m}$ after five months (150 DAP) and the harvest was carried out in November (180 DAP). The authors highlight that organic management was adopted, so no insecticides or fungicides were applied during cultivation.

Surveys in the aboveground part of the plants were held weekly, up to November. When insects were seen eating the leaf blade, they were collected manually, put in plastic pots, cataloged and sent to the laboratory to be identified, following standard procedures. The adult specimens, which arrived in the laboratory, were killed and assembled. Those which were in immature stage were maintained on natural diet based on yacon leaves until adult emergence. When the harvest was performed, roots were also surveyed.

\section{RESULTS AND DISCUSSION}

Only in the aboveground part, the authors observed aboveground feeding insects; neither presence of insects underground nor symptoms of root

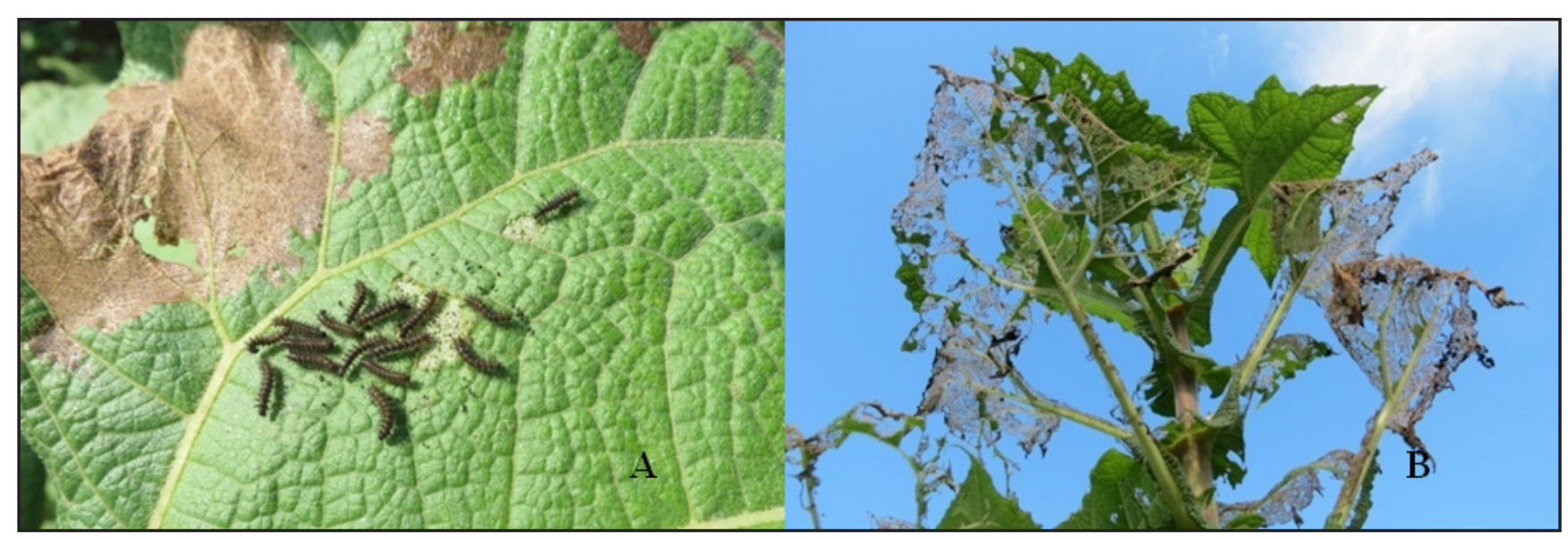

Figure 1. Caterpillars of C. lacinia saundersii feeding on yacon leaf (A), yacon plant with attacked leaves (B) \{lagartas de C. lacinia saundersii alimentando-se em folha de yacon (A), planta de yacon apresentando folhas rendilhadas (B)\}. Alegre, UFES, 2013. 
attack were detected. From all the insects cataloged causing damage to yacon plants, three species of Coleoptera and two species of Lepidoptera were observed. In the first order were identified Lagria villosa, belonging to the family Lagriidae; Cerotoma arcuata and Diabrotica speciosa, belonging to the family Chrysomelidae. Among Lepidoptera were identified Spodoptera eridania, family Noctuidae, and Chlosyne lacinia saundersii, family Nymphalidae.

The Coleoptera collected are considered eventual pests mainly of Fabaceae family crops, as shown by Fernandes et al. (2010) in a survey carried out in the bean crop. On the other hand, S. eridania caterpillar is a highly polyphagous insect and it is able to cause economic damage to crops such as cotton, soybeans, tomatoes and corn among others (Souza et al., 2013). Prior to yacon planting, the field was used to grow jack beans, Canavalia ensiformis, this fact could contribute for introduction and multiplication of insects in this area.

Despite all the insects mentioned cause defoliation, only $C$. lacinia saundersii, kown as sunflower caterpillar, stood out, being observed throughout the crop cycle and showing high damage potential (Figure 1). Defoliation concentrated in the middle third of the plants. During the first growth stage, caterpillar fed by scraping the upper epidermis of leaves and, in the following growth stages, they also consumed the chlorophyll parenchyma, leaving just midribs and lower epidermis residues. Feeding extended from evening to dawn, and during the day, the caterpillars remained protected under the leaf debris.

Sunflower caterpillar is one of the most important pests of sunflower crop and it is the main target of insecticide applications, due to intense defoliation (Cunha et al., 2010). The presence of $C$. lacinia saundersii in the area where the yacon cultivation was carried out was already known, since the caterpillars were constantly found feeding on weeds like Acanthospermum hispidum and Parthenium hysterophorus. The latter is abundant in the region and, according to Justus et al. (2003), is a good host for this caterpillar. In addition, yacon and sunflower crops are both of the family Asteraceae, and this fact could have contributed for the acceptance of yacon as $C$. lacinia saundersii host.

Presence of natural enemies, especially orders Dermaptera (earwigs), Neuroptera (silkworm) and of the Coccinellidae family (ladybugs) in yacon cultivation area may have contributed to reduce injuries. The maintenance of natural enemies is one of pest control strategies that can be adopted in yacon cultivation, as well as the use of sunflower plants as traps for C. lacinia saundersii and the elimination of host weed pests.

Survey and identification of herbivores which promote injuries in yacon plants constitute the first action for the development of a Plant Health Management Program for this crop in Brazil. Future studies are necessary in order to indicate the potential of each cataloged species.

\section{ACKNOWLEDGEMENTS}

CAPES (Coordination of Improvement of Higher Education Personnel) for PhD scholarship to the first author. FAPES (Foundation for Research Support and Innovation of Espírito Santo) for capixaba researcher scholarship to the second author. To CNPq (The National Council for Scientific and Technological Development) and FAPES for financial support for the research.

\section{REFERENCES}

ALBUQUERQUE EN; ROLIM PM. 2011. Potencialidades do yacon (Smallanthus sonchifolius) no diabetes Mellitus. Revista Ciências Médicas 20: 99-108.

ASAMI T; MINAMISAWA K; TSUCHIYA T; KANO K; HORI I; OHYAMA T; KUBOTA M; TSUKIHASHI T. 1991. Flutuation of oligofructan contents in tuber of yacon (Polymnia sonchifolia) during growth and storage. Japanese Journal of Soil Science and Plant Nutrition 62: 621-627.

AYBAR MJ; SÁNCHEZ-RIERA AN; GRAU A; SÁNCHEZ SS. 2001. Hypoglycemic effect of the water extract of Smallantus sonchifolius (yacon) leaves in normal and diabetic rats. Journal Ethnopharmacol 74: 125-132.

CUNHA F; SOSA-GOMEZ DR; ALEXANDRE TM; SILVA JJ da; MOSCARDI F. 2010. Genetic diversity of the sunflower caterpillar (Chlosyne lacinia saundersii) (Lepidoptera: Nymphalidae) populations determined by molecular RAPD markers. Anais da Academia Brasileira de Ciências 82: 1-10.

FERNANDES FL; PICANÇO MC; FERNANDES MES; XAVIER VM; MARTINS JC; SILVA VF. 2010. Controle biológico natural de pragas e interações ecológicas com predadores e parasitóides em feijoeiro. Bioscience Journal 26: 6-14.

GENTA SB; CABRERA WM; MERCADO MI; GRAU A; CATALÁN CA; SÁNCHEZ SS. 2010. Hypoglycemic activity of leaf organic extracts from Smallanthus sonchifolius: Constituents of the most active fractions. Chemico-Biological Interactions 185: 143152.

HERMANN M; FREIRE I. 1998. Compositional diversity of the yacon storage root. In: HERMANN M; FREIRE I (eds). Impact on a changing world .Lima: Centro Internacional de la Papa. p. 199-242.

JUSTUS C; PASINI A; OLIVEIRA EDM. 2003. Biologia e preferência da lagarta do girassol, Chlosyne lacinia saundersii (Lepidoptera: Nymphalidae) na planta daninha losna branca, Parthenium hysterophorus (Asteraceae). Neotropical Entomology 32: 163-166.

LACHMAN J; HAVRLAND B; FERNÁNDEZ EC; DUDJAK J. 2004. Saccharides of yacon (Smallanthus sonchifolius) tubers and rhizomes and factors affecting their content. Plant soil environment 50: 383-390.

MAIER RJ. 2012. Informações à Imprensa: Assessoria de Comunicação - Ceasa-ES. Disponível em: <http:// www.faes.org.br/ noticias_detalhe.php?Cod_Noticia $=2283>$ Acessado em 12 de dezembro de 2012.

MALDONADO S; PIZARRO PL; MARTÍNEZ V; VILLATARCO M; SINGH J. 2008. Producción y comercialización de yacón (Smallanthus sonchifolius) em comunidades rurales del Noroeste Argentino. Agroalimentaria 26: 119-125.

MANRIQUE I; HERMANN M; BERNET T. 2004. Yacon - Fact Sheet. Peru: International Potato Center (CIP), 2004. Acessado em 31 outubro 2014. Disponível em: www.cipotato. org/artc/cipcrops/factsheetyacon.pdf.

MANRIQUE I; PÁRRAGAA. 2005. Conservación y uso de la biodiversidad de raices y tubérculos Andinos: Uma década de investigación para el desarrollo (1993-2003). Jarabe de yacón: principios y procesamiento. Lima: Centro Internacional de La Papa. 40p.

MOSCATTO JA; PRUDÊNCIO SH; HAULY MCO. 2004. Farinha de yacon e inulina como ingredientes na formulação de bolo de chocolate. Ciência e tecnologia de alimentos 24: 634-40.

SANTANA I; CARDOSO MH. 2008. Raiz tuberosa de yacon (Smallanthus sonchifolius): 
potencialidade de cultivo, aspectos tecnológicos e nutricionais. Ciência Rural 38: 898-905.

SEMINARIO J; VALDERRAMA M; MANRIQUE I. 2003. El yacon: fundamentos para el aprovechamiento de un recurso promisorio. Lima: Centro Internacional de la Papa (CIP), Universidad Nacional de Cajamarca, Agencia Suiza para el Desarrollo y la Cooperación (COSUDE). 60p. Online. Disponível em: <http://www.cipotato.org/ market/PDFdocs/Yacon_Fundamentos password.pdf $>$ Acessado em 18 de junho de 2012.

SOUZA BHS; BOTTEGA, DB; SILVA, AG; BOICA JUNIOR, AL. 2013. Feeding nonpreference by Spodoptera frugiperda and Spodoptera eridania on tomato genotypes.
Revista Ceres 60: 21-29.

VILHENA SMC; CÂMARA FLA; KAKIHARA ST. 2000. O cultivo de yacon no Brasil. Horticultura Brasileira 18: 5-8.

WORLD HEALTH ORGANIZATION (WHO). 2004. WHO guidelines on safety monitoring of herbal medicines in pharmacovigilance systems. Geneva: WHO. 82p. 